\title{
The Politics In Higher Education: The Contemporary Crises In Higher Education In Nigeria: A Consequence Of Fundamental Political Manipulations Of The Educational System (Military And Civilian Era)
}

\author{
Dr. (Mrs) Celestina Imade Harry \\ Senior Lecturer (History And Policy Of Education), \\ Department Of Educational Foundations, Faculty Of Education, \\ University Of Port Harcourt, Choba.
}

\begin{abstract}
The Politics in Higher Education: The contemporary Crises in Higher Education in Nigeria is a consequence of fundamental political manipulations of the educational system - at both the federal and state levels. The government did not take the economy of the country into consideration. This had now made almost all the institutions of higher education of learning in Nigeria to face the financial constraints. For instance look at the specialized Universities of Agriculture at Abeokuta and Makurdi and the Faculties of Science and Technology in Nigerian universities are all facing the same financial problems as the Faculties of Arts and Social Sciences. Furthermore, libraries in most higher institutions of learning today are ill-equipped. Therefore, establishing higher institutions here and there without maintaining the already existing ones is not in the best interest for national development.
\end{abstract}

\section{INTRODUCTION}

The background of politics and higher education started right from the colonial era, during this time it was the opinion of some elite that even if the colonial government were to establish full universities some fundamental questions had to be answered. For instance, how would the academic standards of such institutions so started be guaranteed? Where would academic staff be recruited from? What assurance could be given that the degrees so awarded would be granted international recognition? Are there enough African students with advanced level certificates that would justify the expenditure on such a bold venture? Would each colony have its own university or should there be one single university for the whole British West Africa? If so, where should it be located and how should it be funded? Adesina (1988) it was in response to the above questions that the Elliot Commission was set up. The commission travelled extensively in West Africa, receiving memoranda from the peoples of the territories, colonial administrators and individuals connected with higher education in the colonies.

The commission ended up submitting two reports:

1) A majority report that recommended the setting up of a university college in Nigeria and the Gold Coast (Ghana) and that certain reorganizations and new development of higher education be carried out in Sierra Leone in close connection with Fourah Bay College.

2) A majority report that criticized the establishment of three university colleges. It was argued in some quarters that West Africa did not have enough students to justify the creation of three universities colleges nor did Britain have adequate academicians to staff and fund the three university colleges in West Africa alone. The committee therefore recommended the immediate establishment of only one institution of 
university rank to serve the whole of British West Africa. They also proposed that it be entitled the West African university college and be located in Ibadan in Nigeria.

Elliot commission was the Asquith commission whose terms of reference was the examination of higher education in the colonies generally. The recommendations of the Asquith commission were necessary of a general nature since they dealt with the colonies in general. Some of there are:

1) That in the interest of higher education in the colonies, universities should be established at an early date to serve those areas where they do not exist.

2) That those universities should begin as university colleges, and in the interim before attaining full university status, the colleges should enter into special relationship with London university. This was to ensure that while the standard of London university was main maintained, the syllabus was adapted to local conditions.

3) That an inter-university council for higher education should be created, through which co-operation in respect to staffing between the British universities and the new colonial universities could be considered.

4) That an appropriate part of the funds available under the colonial development and welfare should be specifically as provision for the establishment of universities in the colonies (Okafor, 1971:88-89).

It will be recalled that the Asquith commission had recommended the setting up of an interuniversity council for higher education in the colonies. It was a delegation of the interuniversity council led by Sir William Hamilton Fyne that reappraised the needs for higher education in West Africa. The delegations main problem was to decide whether there should be one or more universities. The delegation endorsed the majority report's view of Elliot's commission that the Achimota college could in fact be converted into a university college. Consequently, the colonial office reversed its earlier decision on the minority report in view of the strong public demand in the Gold Coast (Ghana) for the establishment of a university college there and of the evident willingness of the people of Ghana to provide the necessary financial support. It was perhaps fortunate for Nigeria that because of her size, both the minority and majority reports of the Elliot commission agreed on the establishment of a university for Nigeria as well as locating it at Ibadan, a suggestion also endorsed by the Fyne delegation.

The establishment of Nigeria's first university was the ultimate outcome of the Elliot's commission. In January 1948, the remains of the Yaba Higher College staff and students were transferred to Ibadan to form the nucleus of the new university college. This was at a temporary site at Eleyele, Ibadan in a disused army huts from the onset the University of Ibadan was vigorously attacked by the public and press. Three major forces were said to have obtained the college from the start, first the principal did not appear trained or experienced in any way for the administrative responsibilities, he was called upon to shoulder at Ibadan. Secondly, he had very little guidance on the nature of his new job as he admitted later in his reflection. The birth of Nigeria's university 1948, has no governing body, no academic staff, no students and only a rather tenuous link with an advisory body in London. I had to decide when and where the college was to open and what would be the scope of its work. There was also alledged "racial discrimination" in the appointment of staff in the expatriate teacher's cadre, British were paid more than their Nigerian counterparts, and were generally better trained. It was also believed in Nigerian circles that the college was unduly strict in its standards in order to frustrate Nigerians. 
It is difficult to say whether the criticisms and attacks of the university college authorities were justified. Could it be that the distrust of the college stemmed from the fact that it has been set up by the colonial government, and the politics of the time was marked by a general distrust of the colonial governments? Dr. M. Flanks the first principal did little to allay the fears of Nigerians. For example, a great majority of the letters were British. He also did not feel the urgent need to identify the college with Nigerian's aspirations. Eventually, the Nigerian legislature the general public and colonial office waded in and Dr. Kenneth Mellanby was replaced by Sir Sydney Phillipson as chairman of the provisional council and as principal by D.I.T. Sanders. Inspite of the many indefencible charges against him. It was to the credit of Dr. Mellanby that he nursed Nigeria's first university at its formative crucial stage, gave it international recognitional and started the university greatest pride today - it medical school. Dr. Saunders succeeded by Dr. John Parry in 1956.

It was under the principalship of Dr. Parry that the institute of education and the new department of economics and Islamic studies were started - his departure in 1960 paved way for the first Nigerian principal of the college. Mr. Kenneth Dike, who also became the first ViceChancellor in 1962, when the institution ended the fourteen years of apprenticeship under the University of London and started awarding its own degrees. Soon after independence, in 1962 the National Universities Commission (NUC) was set up to develop guidelines for the most efficient and economic system of university development. A National Board for Technical Education (NBTE) was also set up United Nation in 1977 to coordinate the development of technical education. According to Guobadia, A.T. (1983) at present no organized body seemed to exist for the co-ordination of colleges of education at national level. The end of the civil war on January 12, 1970 marked the dawn of a new decade in which there was intense federal government activity leading to considerable expansion at all levels and in all types of educational institutions. According to Orubite (1993) at the end of the Nigerian civil war in 1970 , there were already five full-fledged universities in the country.

\section{THE FIVE UNIVERSITIES IN NIGERIA}

These are the federal government owned Universities of Ibadan and Lagos, the Ahmadu Bello University, Zaria owned by the Northern regional government (later on Northern States), the University of Ife (now Obafemi Awolowo University, Ile-Ife, owned by the western region (later Western States); and the University of Nigeria owned by the Eastern region (later jointly owned by the East Central and South Eastern states).

Having seen that up to 1971 most of the universities were in the south, political considerations seemed to have played a more crucial role in the analytical distribution of higher institutions of learning in Nigeria. This, to a large extent was partly the product of the political instability that followed immediately after independence which eventually found expression in a 30 month civil war. As Kosemani (1982:6) indicates the problem of educational imbalance might have contributed to the uneasiness and suspicion that preceded the turbulence of the first decades of independence. Redressing the educational imbalance among the various ethnic groups and especially between the North and South, came a touching political issue which has serious implications for the tenuous problem of national unity. For instance, before 1975 there were six universities in Nigeria. Five of these in the South and one in the North, and out of the five in the South, four were in the Western section. There was thus an obvious geographical imbalance in the establishment of higher institutions of learning in Nigeria. However, when it is realized that Nigeria had in the south and in the seven second generation universities in the country. The second generation universities are University of Port Harcourt, Calabar, Maiduguri, Jos, Bayero, Kano, Usman Dan-Fodio, Sokoto and Ilorin. Third generation universities are in educationally less developed states. The aim of these schools was to assist these designated areas in 
improving their secondary education base through a remedial education and to create alternative but accelerated avenue for manpower development in these states declared educationally less developed.

The schools of basic/advanced/preliminary studies eventually operated two programs.

\section{THE REMEDIA EDUCATION AND THE PRE-DEGREE SECTION}

The remedial section is geared towards the improvement of the school certificate of students. The main aim of the programme is to compensate for the weak secondary education base and thus enhance students chances of gaining admission into institutions of higher learning as envisaged in the third development plan.

The Pre-degree Programme: This is a specialized section of the school of basic studies which prepares school certificate holder for direct entry into universities.

\section{THE SCHOOLS OF BASIC STUDIES/ADVANCED/PRELIMINARY STUDIES}

It was in reaction to the problem of educational inequality among various section of the country that the federal government of Nigeria. In the Third Development Plan 1975-1980 declared some states educationally less developed and others educationally advantaged. In that document (Vol. 1:249) the government stated that condition will be created for students in the former category to improve the quality of their certificates so as to qualify for admission into the universities. Part of the conditions created was the establishment of the schools of basic, advanced/and preliminary studies in areas declared educationally backward. These schools were established in all the ten Northern states: Rivers, Cross River and Lagos States, four regions before the civil war and that three of them were in the south, the picture became clearer. This leads us to some political policies towards the improvement of educational imbalance in Nigeria.

The war and its aftermath revealed some states that were educationally backward. Such as Lagos, Rivers, Cross River and most of the Northern states, it was realized that most of these states needed special educational attention. Due to these, the federal and state governments embarked on policy objectives of expanding educational opportunity so as to increase access to all levels of education.

1. Among these policies are schools of basic studies in educationally backward states.

2. Nomadic education in the North

3. Quota system of admission to Nigerian universities

4. The states were mandated to have their own schools

5. The Universal Primary Education (UPE) scheme 1976

6. The establishment of unity secondary schools by the communities

7. The geographical spread of federal institutions

8. The introduction of Joint Admission and Matriculation Board

9. The realization of universities

10. The introduction of Joint Admission and Matriculation Board and those other measures.

In Nigeria, the first attempt to look into the educational needs of the migrant population was initiated in 1970. Recently a service that year, which was set up to look at the educational problems of the nomadic Fulani at Kwoi, Jemaia Local Government Area of Kaduna State, it could not take off until 1982 that an official backing was given to the programme. On September 8, 1980, the National Literacy Day, the Ministry of Education identified women and nomads as groups who have suffered educational deprivation in addition to other social disabilities in the Nigerian society. Dogo-Fai (1988:2) described the nomadic Fulani as 
conservative, educationally disadvantaged, very mobile, with drawn and extremely resistant to change. There was a compensatory scheme targeted at the nomadic Fulani. The nomadic Fulani like all migratory herdsmen all over the world have suffered.

At the official commencement of the scheme in Plateau, Col Onoja the state governor said "the new opportunities will improve rather than undermine the base of the nomadic population. The nomadic will no longer remain the educational retarded section of the state" (Guardian, Saturday, February 20, 1988:16). In the same vein the commissioner of education in Borno State indicated that the scheme is designed to bring education to the door steps of the nomads. In the final analysis educational provision for the nomads will enable them know their rights and privileges as well as engender in them an appreciation of their responsibilities to larger Nigerian society. It should be pointed out that the nomadic education scheme is limited to primary education currently.

\section{QUOTA SYSTEM OF ADMISSION INTO HIGHER INSTITUTIONS OF LEARNING}

The federal government states as either as educationally advanced or educationally less developed. This is reflected in the 1980 Joint Admission and Matriculation Board (JAMB) guidelines for admission into Nigerian universities. According to the guidelines (JAMB/ADM/66, Vol. II, 1985:2) twelve of the nineteen states were declared educationally less developed. The states are Kaduna, Kano, Lagos, Niger, Plateau, Rivers and Sokoto. Nine of these states are in the North. These shows sectional disparity between the North and the South. The political decision is an attempt to achieve unity political stability and enhance equality of opportunity based on a desire to overcome conflict situations. This same political decision has led to the adoption of the quota system of admission into federal institutions of learning at the secondary and tertiary levels of education in 1977. This was created to correct the problem of geographical imbalance in admission to Nigerian universities. The introduction of quota system of admission to Nigeria universities is to engender national unity, political, stability and even economic development in terms of manpower production.

\section{State Takeover of Schools}

With the take-over of schools in the early 1970s was therefore intended to ensure that no child was denied education on account of race ethnicity, social status, religion state, sex, or physical disability and also to be able to control standards with the take-over of schools, state now took over the responsibility for the education of its citizens at the primary and secondary level. Schools became institution of public welfare. The take over of schools by the government gave rise to uniform standard curriculum among the various states divisions, linguistic groups. Subcultural groups as well as previously disadvantaged areas. This also gave rise to increased access which was previously unevenly distributed.

\section{Government Control of Education}

This meant that the suspicion which non-Christians held about western education had been removed. The implication of this, is that acceptance of western education in such areas as the Muslim North which had accused the colonial administrators of unwillingness to extend qualitative and quantitative education to the North was exposed to secular education.

\section{The Universal Primary Education}

Universal primary education (UPE) in Nigeria has its historical background. In 1955, UPE programme of the Action Group government in western region in 1958 and the 1957 NCNC experiment in the eastern region of Nigeria. The Action Group experiment in the western region of Nigeria despite its short coming had a tremendous impart and success on the 
increased enrolment excess in the area where parallel political problems and the action of the catholic mission made the experiment to be a failure.

Then after the government takeover of school in 1970, the federal government introduced the universal free primary education (UPE) in 1976. This singular act of the federal government added meaning to the attempt by the government to democratic education thus enhancing the equality of educational opportunity which according to the National Policy on Education was to create 'a land of bright and full of opportunities for all citizens'. As a result of this UPE every nook and cranny in Nigeria today can boast of at least a primary school.

\section{THE ESTABLISHMENT OF UNITY SECONDARY SCHOOLS}

The federal government in the early sixties had two colleges known as King and Queens College, Lagos. The admission into these colleges depended on quota system. The two unity schools came into existence in order to measure and achieve national unity and integration and to reduce educational imbalance at the post primary level in each state of the federation.

Improving education imbalance in Nigeria, requires looking into the politics and higher education in Nigeria. Various government in Nigeria since the state takeover of schools federal or state, military or civilian - have made efforts to see success to education in the country. This is because without education, there will be no development. The civil war came up because of suspicion among the citizens, lack of appreciation of the "national goal and the fear of domination by others."

In Nigeria, politicians both military both military and civilians at both the federal and state levels have always manipulated the education system to acquire political legitimacy. For instance, at the state level especially in the south, during the short lived second republic, various governments justified the proliferation of higher institutions as their attempt to democratize education.

In the state according to Anuma (1987:22) that the establishment of the Imo State University was Sam Mbakwe's attempt to fulfill an electoral campaign promise. In Rivers State on the other hand, Orubite (1984:103) said that the conversion of the Rivers State College of Science and Technology into a university was Melford Okelo's justification for his electoral success in 1979. In Bendel (now Delta and Edo States) and Ondo, the Unity Party of Nigeria also established the state university in order to fulfill their political promise. In short it was only during this period that Anambra State University was established too. In the North where the education base is weak, the federal government had more emphasis and made provision for higher education there, more than the south. The military takeover of 1983 saw Bendel State University, reduced to the basics. The school of medicine was closed - the faculty of education had its students transferred to Abraka which then became the faculty of education. the merging of Federal Universities of Technology at Bauchi and Markurdi with the University of Jos, Yola with Maiduguri and Abeokuta with Lagos in 1984 shows very clearly that politics rather than need was the politics rather than need was the operating factor in the establishment of these institutions. In fact the establishment of universities of technology at Minna, Yola, Bauchi and Makurdi where the education base is weak before citing others at Owerri, Abeokuta and Akure explains the political manipulations. This will show that the argument of democratization and the enhancement of equal opportunity of education in Nigeria by the federal government cannot be sustained. The core of the crisis in higher education in Nigeria today is pure politics, which did not permit the government to consider the economic implications of it's actions. 
Even the annual admissions to Nigerian universities reinforced the need to have more universities and larger ones in the south. In the 1984/1985 Joint Admission and Matriculation Board summary of applications and provisional admissions into first degree courses in Nigerian universities, the South had a total of 174,789 applicants and 22,977 admissions while in the North the same year had 25,424 candidates seeking admissions while 4,231 were admitted. In the 1985/1986 session the figures were 182,655 applicant for the South with 28,029 admitted, while the North had 28,638 applicants with 2,929 candidates admitted. The figures for 1986/1987 session were for the South 166,863 applicants and 31,829 were given admissions. Whereas the figures for the North were 26,021 applicants and 7,852 were given admissions. For the three years under consideration, the difference between the South and the North were 1984/1985 149,374, 1985/1986 154,017 and 142,642 for the 1986/1987 session all in favour of the South (Kosemani, 1989, p.73).

The establishment of state universities and other institutions of higher learning especially during the 1974/83 period was profoundly influenced by politics. In almost all cases, the multicampus system was suggested and adopted as policy. This is the case with the Rivers State of University of Science and Technology, Orubite (1984:106) part in his inaugural address to the provisional council of the university. The Visitor, Governor Melford Okilo made the policy statement that the university will have campuses located in appropriate and relevant areas of the state. Anuna (1987:20) reflects the same point when he said that "in Imo State the multicampus system came into existence because of political leaders". According to Jones (1986) as quoted in Anuna (1987), the multi-campus idea of Alvan Ikoku College of Education was politically motivated to win favour from communities promised a campus of the institutions and earn their 'votes'.

The continued existence of three full-fledged universities of technology in Owerri, Minna and Akure cannot be justified on account of their students intake and the current economic depression in the country. In the three years for which figures are available, Owerri Federal University of Technology had the following applicants and admissions. In the 1984/1985 session 1,035 (0.5\%) candidates sought admission of which $375(1.3 \%)$ were admitted. During the 1985/1986 session 1,282 candidates applied 429 were admitted. In 1986/1987 session 1,337 applied 538 were offered admission Akure had 323 applicants in the 1984/1985 session of which 211 were taken. In the 1985/1986 session it was 763 applicants and 403 admissions. The figures for the 1984/1985 session, the total number of applicants were 40 with 78 admissions. In 1985/1986 academic year, there were 192 applicants with 223 candidates admitted. In the 1986/1987 session, applicants were 239 with 153 admissions.

It is clear from the above figures that running three universities of technology in the country today is economically unrealistic. To economize our resources all candidates in the three universities could be brought together in one university.

\section{CONCLUSION}

The contemporary crises in higher education in Nigeria is a consequence of fundamental political manipulations of the education system at both the federal and state levels. The government did not take the economy of the country into consideration. This had now made almost all the institutions of higher learning in Nigeria face the financial constraints. For instance, right now, both the specialized Universities of Agriculture at Abeokuta and Makurdi and the Faculties of Science and Technology in Nigerian Universities are all facing the same financial problems as the Faculties of Arts and Social Sciences. Furthermore, libraries in most higher institutions of learning today are mainly ill-equipped. Therefore, we can then see that various governments in Nigeria since the state take-over of schools, federal or state, military or 
civilian have attempted with varying degrees of success to use education for the advancement of national development. Development in the context there is conceived as all the social, economic and other institutional apparatuses employed by society to achieve positive change for itself and its members. Though this was geared to this, it is good for them but we know that too much of everything is bad. Therefore, the political leadership both military and civilian have to look for another way of improving our country economically. Not necessarily to be establishing higher institutions here and there without maintenance. It is good to have few higher institutions of higher learning well equipped and maintained them than to have what we have in Nigeria now. The political leadership of Nigeria should look into the problems facing higher institutions in Nigeria. Rather than establishing new ones whether the educational imbalances or not. This is because the establishment of too many institutions of higher learning in Nigeria in telling on our economy rather than improving it.

\section{References}

Adesina, S. (1988). The development of modern education in Nigeria. Ibadan Heinemann Educational Books (Nig) Ltd.

Anuna, M.C. (1987). Higher education policies in Imo State, 1967-1987: A historical analysis. Unpublished.

Federal Republic of Nigeria (1961). Educational development, 1961-1970. Sessional Paper No. 3, of 1961 Lagos Government Press.

Guobadia, A.I. (1983). Nigerian Educational Trends and Issues. Nigeria: University of Ife Press Ltd. Ile-Ife.

Kosemani, J.M. (1989). University education in Nigeria. The attempt at socio-political balance and national integration. Journal of Education in Developing Areas, Vol. 1, No. 1.

Okabor, N. (1971). The development of universities in Nigeria. London: McCamel of Press Ltd.

Orubite, A.K. (1984). A historical analysis of the development of higher education in Rivers State 1970-1982. Unpublished M.Ed Thesis. Faculty of Education, University of Port Harcourt.

Joint Admissions and Matriculation Board (1988). Guidelines on admission into federal universities, JAMB/ADMS 66, Vol. 1.

Harry, C.I. (1993). Politics and higher education in Nigeria. A seminar paper presented at the Faculty of Education, University of Port Harcourt (Unpublished).

Harry, C.I. (2015). Politics in education and national development in Nigeria. In celebrating our teacher and mentor @ 70. Essays in honour of Professor Joseph Donatus Okoh edited by I.M. Amingo \& S.D. Osaat.

Kosemani, J.M. and Okorosaye-Orubite (1995). History of Nigerian education. Port Harcourt: Abe Publishers.

UNICEF (2004). Nigeria and the rights of the child: The child development department. Federal ministry of women affairs and social development Abuja.

UNESCO (2005). Global education digest comparing education statistics across the world montreal. UNESCO Institute for Statistics. 